RESEARCH ARTICLE

\title{
A Reassessment of Turkey's Import Substitution Strategy: Bureaucracy, Politics, and the International Organizations
}

\section{Emrah Yildiz' ${ }^{1}$}

\begin{abstract}
Following the years of WWII, Turkey and many developing countries performed import substitution industrialization strategy (ISI) on the advice of the International Organizations. These countries expected that the ISI strategy serve their longing desire to build a national industry. In Turkey's case, the policy implementation was conducted under the guidance of five years development plan was prepared by the State Planning Organization (SPO). Initially, the ISI strategy covered the optimistic expectations and Turkey's economy showed unprecedented economic performance during the ISI period. However, the economic growth came to an abrupt end in the late 1970s and Turkey became dependent on foreign resources than ever before. This study aims at clarifying the questions of why Turkey shifted its policy paradigm to the ISI strategy and the role of the SPO in the ISI period referring to the literature on the developmentalism and the developmental state. From this perspective, this study illustrates the discrepancies between the SPO and its counterparts in Japan and East Asian countries and the question of why Turkey could not shift its inward-oriented economic growth model to the export-oriented growth model.
\end{abstract}

Keywords: Import substitution industrialization • Development • Developmental state $\bullet$ the State Planning Organization

1 Correspondence to: Emrah Yıldız (PhD), Institute of Graduate Programs, Ankara Hacı Bayram Veli University, Ankara Turkey. Email: e.yildiz@hbv.edu.tr ORCID: 0000-0002-1597-6669

To cite this article: Yıldız, E. (2020). A reassessment of Turkey's import substitution strategy: Bureaucracy, politics, and the international organizations. Istanbul Üniversitesi Sosyoloji Dergisi, 40, 599-623. https://doi.org/10.26650/SJ.2020.40.2.0100 
In Turkish histography, there is a general tendency to explain drastic paradigm shifts in Turkey with reference to the influence of the international environment over Turkish politics. This tendency to attribute explanatory power to international environment in explaining internal political transformations relegates domestic coalitions to irrelevance. From the perspective of this paradigm, Turkey's transition to the multi-party electoral system in 1946, and adoption of import substitution industrialization (ISI) strategy in the 1960s are results of Turkey's adaption to the post-war Western order led by America. However, as Öniş and Şenses put on (2016), the role of the international environment in shaping domestic policy paradigm shifts does not cover the unfolding of the full story. As they propose, it is necessary to consider the relationship between domestic coalitions and the international environment.

This study aims at clarifying the causes of the shift of Turkey's policy paradigm to the ISI strategy in the 1960s. My argument is that ISI strategy covered the expectations of both domestic coalitions, which emerged against the Democrat Party (DP) administration in the 1950s, and the demands of the new cold war international environment. For this purpose, firstly, I will try to elaborate the postwar twist of democratization which started with the introduction to the multi-party electoral system in 1946. The early scholarly tendency to explain the puzzle of introduction to the multi-party electoral system emphasized the pressures and requirements from Turkey membership into post-war international order led by America (Berkes, 1997). In this section, I will discuss the drastic transformation in Turkish politics in the years between 1946-1960 by focusing on the relationship between the domestic coalitions and the international environment which put the DP into the power. ${ }^{1}$

I will scrutinize the implementation of the ISI strategy in the second section. The ISI strategy had resonated among the developing worlds in the late 1950s. Turkey, like many Latin American countries, transformed the policy paradigm to the ISI strategy on the advice of the IOs. As the ISI served for American strategy aimed at integrated the developing nations into the world market, it also answered the expectations of these countries' desire to build a national industry. In Turkey's experience, I will reassess the ISI strategy as a policy paradigm which was in accordance with the state elites' expectations and needs. To demonstrate my argument, I will evaluate the critics of economic policies and developmentalism among the state elites on the Forum Journal, which is the intellectual home of Kemalist intelligentsia in the 1950s. My argument is that the ISI strategy allowed the bureaucracy to re-seize the control over the economic resources away from the demands of the business classes and elected politicians.

In the late 1950s, the IOs had promulgated idea of establishing a planning agency. This idea had seemed particularly attractive to the state elites and bureaucracy. However,

1 See also the study considering the developments in domestic politics in transitioning to multi-party system in Turkey (Karaömerlioğlu, 2006). 
the elected DP government had resisted this idea of establishing a planning agency because it recalled the experience of full bureaucratic control mechanism over the economy in the early period of the new republic under one party authoritarian regime. To implement the ISI strategy, however, Turkey eventually established a planning agency on the advice of the international organizations (IOs) in September 1960, just four months after the coup d'état that overthrew the elected government of Democrat Party. Even though the State Planning Organization (SPO) was established in the hands of the post-coup army government and it had a strong support of the IOs, it never had a strong state autonomy like its East Asian counterparts had.

In the last section, I will discuss the implementation of the ISI strategy under the guidance of the SPO by referring to the literature on developmentalism and the developmental state. The founders of the SPO aimed at institutionalizing the market criteria into the Turkish economy. However, their optimistic expectations ended with rise of the Justice Party, which was the successor of the DP, in 1965. The conflict between elected politicians and the SPO technocrats caused to diminish the role of the SPO in the preparation of the development plans. In this sense, I will consider the puzzle of the SPO from the perspective of the conflict between the elected politicians and the bureaucracy.

\section{The Postwar Twist of Democratization}

Turkey's introduction to the multi-party electoral system in 1946 is considered a turning point, radically transforming economic and social structure, which was institutionalized under the one-party ruling during 1923-1946 period. During the first two decades of Republican period, Mustafa Kemal Atatürk and his colleagues succeeded in pressuring the opposition through political maneuvering ${ }^{2}$ and administered the country under one party, Republican People's Party (RPP). Thus, the modernization project, aimed at building a secular and industrial society, was conducted without any political resistance or opposition until the midst of the 1940s. In the early period of the new state, the state elites codified the principles, which is called Kemalism, in the party program during 1927-1931 period. Then the state elites amended the principles into the Constitutional Act in 1937. Thus, the bureaucratic elites achieved complete dominance over the state and played an exclusive role in Turkish modernization. The crucial role of bureaucracy in modernization remained determinative on Turkish political agenda in the following decades.

In Turkish historiography, the general tendency to explain the introduction of a multi-party electoral system has claimed that the postwar international cold war

2 Even though the Liberal Republican Party (LRP) was founded by Fethi Okyar on Mustafa Kemal's desire to create an opposition for checks and balances, it was dissolved by its founders as the party became the center of political dissidents in a short time. Mustafa Kemal and his colleagues took advantage of LRP to bringing to light politically dissatisfied people. See also Ahmad (2007), Zürcher (2004). 
environment, symbolized by American power in the Western camp, encouraged Turkey to shift the political system to a multi-party electoral system. In this approach, the postwar democratization of Turkey has been explained as a direct result of Turkey's joining to the Western Bloc. The domestic politics, on the other hand, has not been considered as a way to understand the puzzle. It is clear that international environment has had an influence on shifting Turkey's political system from single party regime to multi-party electoral democracy. However, it should be stressed that the postwar international environment falls short of fully explaining Turkey's political transformation. To provide a clear perspective of postwar democratization, it is necessary to construe the relationship between the postwar international order and the domestic coalitions that would put Democrat Party (DP), emerged in the 1940s, into the power with an electoral victory in 1950. In this sense, Kemalist economic doctrine, which is called etatism, deserves close attention when explaining this social transformation because it underpinned the Kemalist Principles that guided the process of transition to multiparty system as well (Karpat, 2007, p. 72; Köker, 2007)

Even though the bureaucracy implemented secularization at an unprecedented pace, the economic legacy of the Ottoman Empire restricted the new state to form a new economic policy. The new republic had accepted Ottoman's financial liabilities, including foreign trade regime and monetary policy, to the Western Powers on Lausanne Agreement. Moreover, in 1929, the same year of the Great Depression, the new state launched debt discharging schedule. Naturally, the founders embarked on a quest for a policy paradigm which would serve for both building a national industrial economy and preserving Kemalist modernization project. The policy that was called etatism emerged under these difficult circumstances and it was implemented in the years between 1930-1946.

Etatism relies on the state's major role in the economy through economic planning and state economic enterprises (SEEs). In this type of economy, it is obvious that the bureaucracy may keep its advantageous positions within the society by controlling economic resources. In Turkey's case, etatism emerged in the catastrophic days of the Great Depression as a policy paradigm targeted building a national industry (Kerwin, 1995, p .97). However, it was more than an economic policy for the state elites. As the Kemalist intelligentsia discussed in the journal of Kadro, which is the intellectual home of Kemalism, etatism was imagined in the 1930s as a doctrine that shaped political, economic, and social system (Tekeli \& İlkin, 1982, p. 84).

Even though etatism was approved among Kemalist intelligentsia, it is difficult to claim that there is a consensus on etatism in both policy practices and theory. In the early periods of etatism, the policy makers accentuated that it was a temporary policy that required the collaboration between the state and the individuals, even if the 
collaboration never existed. Later, Kemalist bureaucracy perceived etatism as an economic and social doctrine in which the state played a role in the economy through state-owned enterprises and its role was not conjunctural (Tekeli \& İlkin, 1982, p.106).

In the early 1930s, the bureaucracy had strict control over the economy through the SEEs. In these years, the SEEs were promoted in the economy to produce imported basic goods. For this aim, Sümerbank and Etibank coordinated the SEE's investment program and provided intermediary goods to small enterprises (Kerwin, 1995, p.102). The bureaucracy also accommodated import license and monopoly rights to emerging bourgeoisie, thus facilitating the birth of the new Turkish bourgeoisie in the hand of bureaucracy (Borotav, 1995; Kerwin, 1995). However, expanding domains of etatism created its own contradictions. At the end of the decade of the 1930s, emerging bourgeoisie became a threat for the state elite and peasants were discontented with etatism. As emerging bourgeoisie felt themselves insecure due to the interconnectedness between economy and the state. The peasant and landlord, on the other hand, were burdened with the cost of etatism. As Birtek points out, the distribution in the economy was unfair, as agriculture sector financed etatism's industrialization projects. (Birtek, 1995, pp. 145-146). Thus, etatism developed a national industry but it paved the way for the rise of Democrat Party which represented the discontents of rural economy as well as the new bourgeoisie. (DP).

Before proceeding to the debate on the rise of Democrat Party, it is important to highlight some of the details about the economic and social consequences of etatism. In 1950, the year when DP came into power, while the SEE's share in total output and value added were $36.6 \%$ and $45.6 \%$ respectively, its share in total labor force was $50 \%$ (Tüzün, 1999, p. 150). The economic composition shows that etatist policies created a private capital accumulation which depended on bureaucracy. The concerning data showing the role of bureaucracy in Turkey's economy illustrates that $75 \%$ of companies built in the years between 1931-1940 were established by bureaucracy (Soral, 1974, p. 116-117). Peasants and landlords, however, continued to undertake the cost of etatism, thus the share of agriculture sector shrank, especially during the years of WWII. The policy implementations of the war years convinced the emerging bourgeoisie, landlords, and the villagers to take the same side of the opposition against the one-party regime that created and implemented etatist policies.

During the war years, Turkey was obliged to keep a one-million-soldier army ready, even if it had proclaimed neutrality. If it is considered that $85 \%$ of the population lived in rural area and mobilized soldiers were the lost manpower of agricultural production, then it can be better understood the impact of the WWII in transforming Turkish politics. In these years, the government implemented a set of excessive policies aiming to ensure economic stability including drudgery, confiscation, and heavy taxes. Pamuk 
provides examples from a couple of policy implementation which laid a burden on the peasant and landlords. In the years of wartime, the government enacted the National Protection Law, which gave extensive authority to buy grain products at below-cost prices and forced works for drudgery (Pamuk, 1991).

Additionally, to compensate the loss stemming from selling products at below the cost to bourgeoisie, state-owned enterprises sold products to consumer at the high prices level. Thus, general consumers of society held the bureaucracy responsible for these high prices, unfair conditions and inequality gap (Karpat, 1962, p. 309). Moreover, it should be mentioned that secularization from above had not been adopted by the large majority (Birtek, 1995). Hence, they perceived the state elites as political actors protecting the status quo and imposing a cultural agenda. This perception would be major determinant in explaining Turkish politics after 1945.

Writings of Yakup Kadri Karaosmanoğlu, one of the ideologists of the Kemalist regime, illustrate the dissatisfaction of peasant and landlords and help us understand the political atmosphere of the midst of 1940s. Karaosmanoğlu alerted the government against the dissatisfaction of the peasant and landlords, warning it that these groups will join an opposition as soon as possible (Karaosmanoğlu, 1968, p. 159). Karaosmanoğlu's confessions about the economic failure of Kemalism can be thought as the harbingers of economic and social transformation in the late 1940s, when economic conditions forced the government to take an action for liberalizing the economy. By the midst of the 1940's, Kemalist intelligentsia conceded the necessity to rectify and reform the Kemalist ideology. As it will be discussed in the next chapter, the debates on "liberal Kemalism" and "liberal etatism" would have influence in setting up the State Planning Organization.

On the side of new bourgeoisie, there was growing discontent with the bureaucratic control mechanism. Initially bourgeoisie had benefited from the interconnectedness between the state and the economy in its emerging era, and it was aware that capital accumulation without the state incentives was difficult. However, the excessive policy implementation of the wartime felt insecure them. This dilemma of bourgeoisie, benefiting from state incentives while complaining about state control, would remain as a perplexing question in modern Turkish history. As Buğra emphasizes, the key role of the state in the economy has made business circles feel insecure due to uncertainty in the market (Buğra, 1991, p. 158). The new bourgeoisie's experience of excessive wartime policies illustrated the bureaucratic power on the economy.

One of the most controversial policy implementations in the years of WWII was the capital levy taxed on bourgeoisie, which was imposed only on non-muslim bourgeoisie with the claim that they prospered from exorbitant prices in the war era. Owen and Pamuk show that $65 \%$ of the total tax revenue was collected from non- 
Muslims, and 70\% of this revenue levied in Istanbul (Owen \& Pamuk, 1999, p. 26). The capital levy implementation indicates that the state elites intented to promote secular-nationalist Turkish bourgeoisie, yet these harsh policies intimidated bourgeoisie because they may have a similar fate with non-Muslim bourgeoisie.

Following the years of WWII, the ruling party liberalized economic and social policies. Firstly, it proposed the Land Reform -aimed at redistribution of land in favor of small farmers- for the party agenda in 1945. By doing so, the government sought gaining the support of villagers. However, the landlords and their representatives within the ruling party put severe resistance to the proposal. Unlike the previous decade, the agricultural sector was expected to become the engine of economic growth through integrating Turkish economy into the world market. The landlords aimed to draw advantage from the postwar international order. As Birtek stresses, landlords perceived that the ruling party was in quest of further controlling the agriculture sector with the idea of land reform (Birtek, 1995, p. 159). The land reform was not implemented due to the strong opposition, and the dissident landlords splinted from the RPP to found the Democrat Party (DP) in 1946.

At the same year, after the controversial election in 1946 (when votes were cast open but counting was in done secretly), RPP won the election and Democrat Party seated in parliamentary assembly as an opposition party. RPP protected its power for the next four years and maintained performing liberalized economic and social policies to adapt to postwar order. After joining the Western Bloc, Turkey expected foreign aid and integration to the world market. However, etatism was not compatible with the international environment promoting market forces. Naturally, etatism was criticized in the context of the postwar developments, and it was redefined in İstanbul Economic Congress in $1948 .^{3}$ The new etatism was defined as a system encouraging the private sector through investing in high-cost infrastructure project. Indeed, the debates of new etatism reflected American postwar strategy. In the end of the 1940s, American experts prescribed liberalization in the economy and stressed that Turkey should make preference on its own comparative advantage in agriculture products in the international market (Thornburg, 1949). However, the ruling party felt short in covering the expectations of landlords and villagers, and as a result, eventually Democrat Party came to the power by receiving the votes from villagers, liberal intellectuals and urban middle classes in 1950 .

As it was expected, the DP government promoted liberal economic policies in harmony with the postwar international order. Turkish Economy integrated into the world market by exporting agricultural products, and thus agriculture sector's share in GNP rose to $44.7 \%$ in 1953 , while the share of manufacturing declined to $13.4 \%$

3 Tekinalp (1949, p. 14-15), first and foremost, stresses that Turkey's institutional environment under etatism makes bourgeoise feel insecure. 
(Tüzün, 1999, p. 152). However, following year, the international market shrank and agriculture revenues declined sharply. Moreover, the DP government had difficulty to find foreign aid to stimulate the economy in these years. Although Democrats criticized state intervention in the economy, the state remained the key player in the economy with the policy of agricultural mechanization and highway-construction-led modernization fueled by foreign resources.

Agricultural mechanization and highway-led modernization, on the other hand, triggered domestic migration and urbanization. The percentage of urban population rose from $25 \%$ to $32 \%$ in the years between 1945-1960 (TÜIK, 2012). Increasing urban population altered the workforce composition, as the number of employees in private enterprises which employed more than ten workers increased three times and reached 325.000 (Singer, 1977, p. 242). The new urban workforce raised housing demand, and as a result, construction industry increased around $25 \%$ per year in the years between 1950-1953 (Singer, 1977, p. 293). The rising housing demand encouraged private business to make investment on construction and housing sector, rather than building a national industry, and therefore $60 \%$ of private investments flowed into construction and housing sector during the Democrat Party ruled decade from 1950 election to 1960 coup d'etat (Tüzün, 1999, p. 153).

Paradoxically, the role of state in the economy expanded despite the liberalization in the 1950s. The government had no other alternative than implementing inflationary policy to protect its power. It did not even see any harm on reviving the National Protection Law, which enabled government to have control over the prices by strict restrictions. In the midst of the 1950s, America was reluctant to support Turkey due to lavish economic policies, and pressured Turkish government to establish a planning agency. The DP government, however, opposed the idea of planning economy since it evoked bureaucratic control mechanism on the economy. Under sluggish economy, the Democrats preferred implementing import restriction and subsidizing agriculture. The severe restrictions on the economy lasted till 1958 and Turkey accepted an offer of stabilization program, according to which the OECC secured credit loan of $\$ 225$ Million to the government for restoring balance deficit (Okyar, 1960, p. 243). The Stabilization Program included devaluation, liberalization on import regime, and building a planning organization to coordinate investments.

Building a planning agency occupied the agenda of Forum Journal, which was the voice of liberal values against the DP's authoritarian policy measures. Forum intellectuals, parallel with foreign experts and the IOs reports, proposed that the planning body be managed by a cadre of high-skill technocrats (Okyar, 1954). During the decade, the state elites -intellectuals and bureaucracy reconsidered Kemalism to adapt it to post-war periods. Moreover, multiparty election system involved taking 
social demands into account when any party come into the power. As it mentioned above, Democrat Party satisfied the domestic coalitions -included new bourgeoisie, landlords, urban middle class, and conservative villagers- that emerged against the Kemalist elites. However, the new coalition was uncomfortable with the DP authoritarianism and sluggish economy. The social transformation forced Kemalist elites to rethink the idea of development, which included liberal values. As we will discuss in the next chapter, the idea of development and the 1961 Constitution, as developed by Kemalist bureaucracy, were compatible with both international environment and domestic demands.

The DP felt insecure and hesitant in its earlier days in power because Democrats had a suspicion that the opposition Party, RPP, had close connections within the army and the bureaucracy, and could overthrow them if DP introduced too many changes. Furthermore, they were aware that a planning agency would be obstacle to subsidizing agriculture and private business circle. On the other hand, even though private manufacturing increased its share against the public in the DP period, private business circles were uneasy about political and economic atmosphere since DP had no more endurance left (Zürcher, 2004). The coalition which put Democrats into the power was shaken at its foundation due to economic and political disturbances. As industrial bourgeoisie demanded more protection in the internal market, merchants and landlords insisted on external trade through the state incentives. That is to say, a new coalition between industrialists and the state elites, emerged against the DP government. Under this political atmosphere, Democrats performed authoritarian policy measures instead of implementing reformist and rehabilitative policies to protect its position. Consequently, authoritarian government could not resist to destructive opposition and Turkey witnessed the Military Coup in 27 May 1960.

\section{The Political Economy of Import Substitution}

Even though the Democrat Party had announced that it would promote economic liberalization in the election bulletin of 1946, it performed severe restrictions on foreign trade in the late 1950s. During the period, the idea of planned economy resonated among Kemalist intellectuals and bureaucracy, who discussed Turkey's political, social, and economic agenda on the Forum Journal. According to the Forum intellectuals, the Democrat Party endangered Kemalist modernization and its economic policy was not more than an economic catastrophe. Therefore, Turkey should establish a planning body which has the control over economic resources to canalize scarce resources for rapid development.

In this section, I will discuss the establishing process of the State Planning Organization and import substitution. I choose Forum Journal as a starting point of 
discussion to understand the topic. ${ }^{4}$ There are several reasons why the Forum Journal deserves close attention to enlighten the puzzle of import substitution and the State Planning Organization. First, the Journal was the intellectual home for Kemalist intelligentsia who devoted themselves to build a secular and democratic society. For this purpose, Forum intellectuals updated Kemalist ideology for post-war environment: authoritarian Kemalism was replaced by Liberal Kemalism. Second, policy recommendations discussed in the journal were put into practice after 1960 Military Coup and most of the Forum intellectuals were assigned to critical positions in the administration. Third, political institutions, which were proposed by Forum intellectuals to secure Kemalist modernization, were established after the 1960 Military Coup, and those political institutions would shape Turkish politics until the recent past.

The intellectual atmosphere of the 1950s provided an ideological umbrella to the state elites to retake the power in the late 1950s and early 1960s. It is a well-known fact that America promoted planned economic model and import substitution industrialization (ISI) for the developing countries in the 1950s. The ISI regime, which is based on the major role of the state through restriction on import of consumer goods, was performed among developing countries. While the ISI strategy fulfilled developing countries' longing for building a national industry, it was the primer economic strategy for America to expand its industry over the developing countries (Maxfield \& Nolt, 1990). For this purpose, American policy makers encouraged the developing world to implement import-substitution industrialization. Thus, the ISI served for integrating the developing world to the American economy and building international division of labor in the world (Akçay, 2007).

In the post-war era, America promulgated the idea of development among the late industrialized countries through the international organizations (IOs) such as the World Bank and the IMF. These IOs intervened in government policies in many ways. As Hirschman points out, their provision of conditional funding for projects was one of these ways (Hirschman, 1967). In addition to that, norms and ideas spread by the IOs may have an impact on government policies (Meyer et al. 1997). In the latter case, experts working for the IOs could play a key role in shaping policies (Barnett \& Fiennemore, 2004).

In Turkey case, implementation of ISI strategy and the establishment of the SPO show that the IOs intervened in government policies by setting prerequisites for loans, aids, and subsidies with support of experts they provided. The IMF and the OEEC required Turkish government to prepare a plan to receive all kind of aid and loan in the late 1950s (Erder et al., 2003, p. 8). As to the ISI, American big business and the

4 Forum Journal, one of the most influential media during the period, was founded by Nilüfer Yalçın to embed Western values and democracy into Turkish society in 1954. The debates on Forum Journal 1954-1960 were an inspiration to the 1961 Constitutional Act. Most of the writers, who were also dissidents of the Democrat Party administration, took up critical positions in administration after the coup d'etat in 1960. 
IOs played a crucial role in shifting policy paradigm. At the beginning of the 1960s, the big business lobbied for transforming economic policy to the ISI in many developing countries (Maxfield \& Nolt, 1990). Then, Turkey invited experts, who supported establishing a planning institution and gave advice on straightening the sluggish economic growth and finding credit under favorable conditions. ${ }^{5}$ Hereupon, policy makers put establishing a planning institution in their agenda, however, it remained as an uncompleted project because the DP government did not want to create a bureaucratic control mechanism. Eventually, the STO was established in the shade of the army, a couple of months after the 1960 Military Coup.

Establishing a planning body had already occupied Forum agenda since the midst of 1950s. In this decade, as it known that many foreign experts propounded establishing a planning body to coordinate the economy. ${ }^{6}$ According to Forum intellectuals, the DP administration's economic policy did not perform coordinated economic policies, rather it implemented inflationary economic policy to maintain economic growth at the cost of double-deficit. Planning organization, however, would coordinate economic policy and invest scarce foreign resources for rational purposes.

Aydın Yalçın, who is the founder of Forum Journal, agreed with foreign experts and claimed that Turkey was deprive of a planning institution which will coordinate economic life (Yalçın, 1956a, pp. 10-11). According to Yalçın, Keynesian economics, unlike liberalism and Marxism, conformed with Turkey's economic and political agenda because Keynesian paradigm made enable both the state intervention in the economy and building a democratic-social welfare state (Yalçın, 1956b, p. 17). In addition, planned economy model was a perfect-fit prescription for the late industrialized countries to launch rapid economic development (Okyar, 1957, pp. 15-16). For them, planned economy model was not only an economic policy. It evolved into a political discourse in which social welfare and political participation were accentuated (Sakıp, 1958, p. 8).

Turkey's position in the Middle East was defined as a model country in the Journal (Forum, 1958, p. 2). The perception of secular and democratic Turkey in the Western imagination was perceived a buttress for economic development. They considered that Turkey's valuable strategic location may allow it to receive favorable loans and international aid. This view would become clearer, when Turkey's struggle with attracting of FDI in these years is regarded. ${ }^{7}$

5 Fatin Rüștü Zorlu, the secretary of the state of Democrat Party administration, invited Jan Tinbergen to Turkey. Tinbergen's proposal relied on economic planning was parallel with the IOs' recommendations. It should also be noted that the main purpose of the government with the invitation of Tinbergen was to alleviate domestic and international pressure on the government which alleged that DP government was reluctant to perform planned economy due to continuing populist policies. For this debate see also Erder et al. (2003).

6 See also Barker (1952).

7 During the period between 1950-1960, Turkey attracted only \$69 Million private investment, American share in this amount was around \%30 (Oksay, 1967, p. 8). 
Putting emphasis on democratic and secular Turkey, elites insist on Turkey's immutable modernization project. Forum intellectuals expressed that Kemalist modernization was jeopardized in the Democrat Party era since it fell short of internalization of democratic values and institutions in the society. To ingrain secularization and democratic values in the society, Kemalist elites proposed that intellectuals and the state elites should lead the society, that is, the state elites perceived themselves as men of wisdom who inculcate Kemalist principles in Turkish society. A forum writer Ömer Sakıp (1957, p. 7) build a theoretical background for Kemalist reforms:

Revolution is an uprising that starts from the lower layers of the community, moves upwards and forces to overthrow the administration. Reform, on the other hand, is a forward move that descends from top to bottom. In this case, people at work are those who can see and think further than the folk strata and sometimes they need to develop and raise the country despite some of the massive and passive resistance of the masses.

Even though Kemalist elite stressed democratization and secularization, their modernization project was inconsistent with the 1924 Constitution Act in which electoral system was based on plurality voting principle. To Forum intellectuals, the 1924 Constitution Act should be redesigned to guarantee fundamental rights and liberties for minority groups. Their proposals took place in the 1961 Constitution Act; freedom of press, right of assembly and strike, bicameralism, and the constitutional court. The dichotomy is that bicameral senate system and the constitutional court played an anti-democratic role in Turkish politics, contrary to what Kemalist elite alleged in Forum Journal. These establishments had a claim to reject Grand Assembly decisions. In this context, it can be considered that the state elite retook the power through the 1961 Constitution Act. $^{8}$

The 1961 Constitution Act, on the other hand, became a basis for the import substitution industrialization. As it is known, the ISI regime is based on restriction on import goods to reduce country's foreign exchange dependency. In that type of industrialization, imported consumer goods are replaced by domestic production and the internal market fosters the infant industry, that is, the wage rate is crucial for continuing ISI; high income level in domestic markets would trigger IS industry.

In this sense, it can be asserted that the state elite attained two main purposes through the 1961 Constitutional Act. First, expanding individual rights strengthened Turkey's image as a democratic country in the international arena and Turkey continued its Westernization journey as a democratic-social welfare state. Second, the state elite built an advantageous ground for the ISI through promoting rights to strike and establishing labor unions. That it is to say, the 1961 Constitutional Act built a broad consensus among the state elite, employees, and the industrialists (Keyder, 2014).

8 For this debate see also Kayalı (2015). 
Import substitution industrialization strategy had performed poorly in the years between 1954-1958 under the DP administration as a consequence of sluggish economic growth. DP government abolished restrictions on imports and relatively re-liberalized economic policy on the advice of the IMF and OEEC in 1958. Even though the Stabilization Program aimed at relieving the shrinking economy, Turkey entered the new decade with economic and political turmoil which resulted with the military coup in May 1960. The idea of establishing a planning body was reawaken by the state elite and the State Planning Organization (STO) was founded in September 1960, in the hands of soldiers. ${ }^{9}$

As noted above, DP was reluctant to establish a planning body since they considered that it would confine elected politicians. After the military coup, Dr. Koopman, who had come to Turkey on the invitation of DP government in 1959, was of the opinion that the National Unity Government provided favorable conditions for establishing a planning body because he considered that elected politicians would exhibit reluctance due to confining their authority by technocrats (Mihçığlu, 1983, p. 256). At this point, Keyder notes that the coup combines the interests of bureaucracy with the industrialists and workers. While bureaucracy re-seized the control over resources through the SPO and implementing import substitution strategy, industrialists and workers took advantage of inward-oriented capital accumulation (Keyder, 2014, pp. 177-178).

In the case of Turkey, ISI strategy has similarities with Latin American experiences where economic growth was relied heavily on foreign resources. In these countries, ISI aimed at replacing imported consumer goods with domestic production. In order to raise domestic production, state intervention was unavoidable. However, the political climate encouraged the ISI sharply varied in these cases. In Latin American experiences, the ISI was performed under rising nationalism following catastrophic economic crisis (Silva, 2007, p. 69). In Turkey, on the other hand, the ISI was the result of populist policies following the Democrat Party's authoritarian administration.

Import substitution industrialization implemented in the years between 1962-1978 with five-years development plans which was prepared by the SPO. During the period, the bureaucracy played a major role in allocation of resources by import licenses, exchange allocation, imposing protection tariffs, subsidies, and state economic enterprises (SEEs). It is clear that the policy implementations are at odds with market criteria, rather political connections become crucial in that type of economic model.

In the ISI period, Turkish economy displayed an unprecedented economic growth performance, around $\% 7$ per annum (Çeçen et al., 1994, p. 38). ISI strategy transformed economic composition in favor of manufacturing: the share of manufacturing in GNP at 1968 's nominal prices raised from $17.5 \%$ to $21.2 \%$ in the years between $1960-1976$,

9 See also for the establishment and the Structure of the SPO Torun (1967). 
while agriculture's share decreased from $36.5 \%$ to $27 \%$ (Boratav, 1998, p. 105). Even though manufacturing output soared, agriculture maintained its importance due to export proceeds. Until the mid-1970s, agriculture's share in exports was over $70 \%$. At the first stage of the ISI, domestic production was stimulated by the internal market in which the state promoted high wage level, favorable credits, and subsidiaries; economic growth was heavily dependent on domestic savings.

At the second stage of ISI starting in the late 1960s and the early 1970s, the economy became more dependent on foreign resources than ever before. Foreign resources flowed into the economy in the years between 1971-74 was equal to 5\% of the GNP (Pamuk, 2007, p. 256). The economic growth fueled by foreign resources -remittances and foreign credits- explained the question of why domestic producers were reluctant to shift to export-oriented economic model.

As noted above, the state intervened in the economy through import restrictions, exchange allocation, and the SEEs. During the ISI years, the state provided exchange allocations to domestic producers under favorable conditions. Moreover, the state economic enterprises transferred resources to domestic producers through selling intermediate goods at below-cost prices. Once it is taken together with domestic markets which was triggered by high-level wages, it can be understood why domestic producers insisted on maintaining inward-oriented capital accumulation under lacking of any incentives for export-oriented accumulation. As Pamuk stresses, manufacturing sector was expected to rise exportation, however, the exportation/GNP ratio was under $5 \%$ in the early 1970 s; even, $6 \%$ of total manufacturing was exported in 1975-76 (Pamuk, 2007, p. 261).

ISI was implemented to reduce imports, but it caused serious trade deficits and by the end of 1970s Turkish economy was in an unmanageable situation. In the ISI period, share of import in GNP increased from $2.4 \%$ to $8.7 \%$ while share of exports raised only from $1.3 \%$ to $3.2 \%$. In the early 70 s, economic growth continued via workers' remittances and favorable debts. However, in the second half of 1970s Turkey had to accept very high interest rates to find debt and has become one of the most indebted countries. This period started with the motto of rapid development and social welfare, but lasted for only 15 years and deceptive welfare was financed by external sources.

As a late industrialized country, in Turkey import substitution was seen as a mandatory policy regime rested on the coalition between the state elites, businessmen and urban middle class. The fact that import substitution increased state participation in the economy was an issue that the bureaucracy had already desired, and it was embodied with the SPO. However, as I will discuss in the next section, the SPO technocrats failed at institutionalizing a strong state autonomy and elected politicians alleviated bureaucratic control over the economy. For elected politicians, state autonomy evoked overwhelming bureaucratic control mechanism in the early years of new 
republic. Even though the early planners never envisioned the SPO would be a superministry like Japanese MITI, institutionalizing state autonomy disturbed both elected politicians and business circle.

\section{Turkey, Developmentalism and the Developmental State}

Initially, the army and the early planners had envisioned the SPO as the state apparatus for the developmental state. The early planners, supported by foreign experts invited by the DP government on the exhortation of the IOs in the late 1950s, had established the SPO to conduct Turkey's national industrialization plan. The early planners' main goal was to build a national, self-sufficient industry. However, their optimistic expectations left its place to economic and political turmoil in the late 1970s. Economic growth, which was fueled by foreign resources since the early 1960s, came to an abrupt end by the late 1970s when Turkey faced unmanageable macroeconomic instabilities.

Turkey's experiences with the import substitution industrialization can be compared to Latin American and East Asian countries. On the one hand, the former implemented inward-oriented economic growth. East Asian countries, on the other hand, promoted export-orientated growth under the control of the developmental state apparatus. While comparing the Turkish case with these two models, I will refer to the literature on developmentalism and the developmental state to answer the question of why Turkey failed at building a developmental state.

The concept of the developmental state, which was first used by Chalmers Johnson in his groundbreaking work MITI and the Japanese Miracle to explain Japanese economic growth, is often used to explain East Asian industrialization (Amsden, 1989; Woo-Cumings, 1999). In the classical definition of the developmental state by Chalmers Johnson, nationalist ideology and the goal of industrialization motivates the developmental state. The state management of the economy, which is based on the combination of selective state interventionism to the strategic sector and the market economy, is defined as the distinctive characteristic of the developmental state (Johnson, 1982, p. 19).

In his formulation, the developmental state has the following features: economic growth, productivity, and international competitiveness (Johnsons, 1982). To fulfill the goal of industrialization, the highly-talented and small-scale meritocratic bureaucracy plays a key role by guiding the market through a pilot agency. The pilot agency is the institutional link between the state elites and the private sector, which makes sure that the private business interests and the strategic industrial policies become compatible. At this point, Johnson stresses the crucial role of the bureaucratic elites in the economy as the bureaucratic elites requires protection from all the interest groups to set and achieve long-range industrialization (Johnsons, 1982, p. 44). 
As it is addressed previously, the IOs had spread the idea of development in the 1950s. For the developing countries, developmentalism in the form of import substitution industrialization was expected to fulfill their desire to build a national industry. In this sense, the import substitution industrialization (ISI) development was a model that was compatible with the rising nationalism in developing countries against developed countries (Baer, 1984). Turkey's case, however, was partially different from other developing countries. ISI strategy did not only amount to the modernization for Turkish intelligentsia and the state elites but it was also meant to establish an independent national industry, making Turkey an integral part of western bloc. Their staunch belief in Kemalist modernization was the motivation behind the state elites which aimed at integrating Turkey into the Western Bloc by building a self-sufficient national industry (Erder et al., 2003).

In order to achieve the goal of industrialization, the developmental state guides the private actors through a pilot agency. In the Japanese case, the pilot agency, MITI, coordinated the private businesses with state incentives to the strategic sector. The selective state intervention in the economy may raise the question of how the bureaucratic elites avoided decisions of a rent-seeking state. Johnson replies to the question by referring to the distinctive relationship between the state and the businessmen in the developmental state in which the state elites, thanks to the high degree of state autonomy, brings the private interests into conformity with the state's long-range industrialization goal (Johnson, 1999, p. 56).

Even though the State Planning Organization was established with the support of the army just after the 1960 Military Coup, the early planners felt themselves insecure against the politicians and businessmen. It should be stressed that the early planners designed the SPO in harmony with the democratic constitution, and thus they never imagined the SPO as a super-ministry, such as MITI in Japan (Kansu 2004; Erder et al. 2003). Yet, they were very conscious that they would need the support of elected politicians to implement the goal of industrialization in the society. For this purpose, the High Planning Council, the highest body where the plans laid out by SPO are negotiated and concluded, was composed of eight members: the prime minister with the three cabinet members, and the SPO technocrats. Although the composition of the council allowed for relative state autonomy for the bureaucracy against politicians, the SPO technocrats lacked a high degree state autonomy like their Japanese or Korean counterparts.

The question of why the SPO technocrats could not establish a state autonomy, even though they had the support of the army and the IOs, deserves close attention. To provide a clear answer, firstly, we should pay attention to the conflict between the SPO technocrats and the state bureaucracy. Then, I will explain the conflict between the early planners and the politician led to the collective resignation of the early planners from the SPO. 
As it was mentioned in the previous chapter, the SPO was founded on the recommendation of the IOs with the selected cadres and exclusive personnel regime. Initially, the SPO, like MITI, had employed a small-scale, highly talented staff who was sent to the top universities in the USA to enhance abilities. The cadre of technocrats were perceived as a privileged group in the state bureaucracy, although they lacked direct control over the state incentives. The Ministry of Finance, on the other hand, remained old-fashioned because the concept of planning was completely new for them, and the state bureaucracy was in need of scientific knowledge requiring for long-range plans. Inevitably, The SPO's position in the state led to a norm conflict among bureaucracy (Şaylan, 1981, p. 197). The early planners attempted to reform public administration. However, it was not approved due to the resistance of the state bureaucracy. Thus, the SPO had difficulty channeling the state bureaucracy to the goal of industrialization.

The weak state autonomy of the early planners ended up with their collective resignation in 1962, a year after the election. Initially, the early planners had a harmonious and cooperative relationship with the businessmen and the politicians, as the private sector was well aware that the early planners worked under the auspices of the army; the prime minister İsmet İnönü, on the other hand, gave confidence and protection to the early planners in order to protect them from interventions and contradictory policy promises of politicians. However, İnönü was also conscious of the fact that the weak state autonomy would not last for a long time because the coalition government, formed in 1961 elections with the Justice Party (which was the successor of the DP governing party overthrown by the military coup), did not have a consensus on development plans.

The disagreement between the early planners and the politicians came to light on the issue of financing the first five-year development plan. Indeed, the strategic document of the first plan, which included technical elaboration about realization of the objectives in the plan, was approved in 1961 before the election. However, the implementation of the plan would be conducted by the civilian coalition government. The early planners had proposed structural reforms in relation to three fields, which were considered as inimical to the capital accumulation, in order to foster economic development on the strategy document (Milor, 1990, p. 21).

The early planners, first and foremost, were insistent on land reform which aimed at redistribution of farmlands and commercializing the agricultural sector through cooperatives (Sönmez, 1967, p. 41). It was expected that agricultural reform would serve two main goals at the same time. Firstly, it would raise tax revenues from the agriculture sector. The share of agricultural sector in total tax revenue was 4\%, although agriculture share in GNP was around 40\% at the beginning of the 1960s (Ergüder, 1970, pp. 277-278). Second, it was envisioned that marketization in agriculture may provide a cheap labor force for the development of industry. 
As it was mentioned in the previous chapter, the state played a crucial role in the economy through the State Economic Enterprises. These enterprises supplied the private sector with raw materials and semi-finished goods by selling below-the-market prices while buying raw materials from rural producers with much higher price than market prices (Boratav, 1993). Moreover, the SEEs were over-employed due to the fact that they did not have an economically rational personnel regime. The early planners were believed that the achievement of the development plan depended on the efficiency of the SEEs (Milor,1990, p. 22). Therefore, they proposed to adapt the SEEs to the market criteria. Thus, the efficiency of these enterprises would rise, and their financial losses in the general budget would decrease.

The last conflict between the politicians and the early planners was related to the tax reform. Planners estimated an 7\% economic growth per year in the first five-year development plan. However, the realization of the plan was heavily dependent on increasing total investment in GNP to $18.3 \%$, although early planners saw a feasible growth ratio of $14.2 \%$. Even though the government accepted to raise indirect tax rates, it abstained from making a radical tax reform. Consequently, as one of the early planners says, the tax burden in Turkey remained to be smaller than it was in more developed countries (Sönmez, 1967, p. 42).

The reforms package proposed by the early planners aimed at adapting Turkish economy to the market criteria in the long range. The secondary goal of the reforms was to finance the developmental plans with domestic funds. As Üstünel, one of the founders of the SPO, stresses, the low saving propensity rate at $7 \%$ left much to be desired to finance the development plan (Üstünel, 1967, pp. 135-138). Otherwise, it was difficult to sustain macroeconomic stabilities, which is pre-requisite for the developmental state.

Yet, the civilian coalition government rejected making the structural reforms and it put the pressure on the early planners to declare $7.6 \%$ rate of growth for 1963 , although this growth rate was calculated to be only $6.5 \%$. Rejecting these political pressures, the founders of the SPO resigned in 1962. Consequently, the weak state autonomy could not institutionalize, and eventually the idea of autonomous state development planning was abolished following the transition to the civilian government rule.

With the rejection of the reform propositions, the only way of financing the development became clear: the development plans would be financed by the IOs credits and remittances. That is, technocrats would never perform strict fiscal financial and monetary policies like their French or Japanese counterparts did (Johnson, 1982; Loriaux, 1999). In this sense, the achievement of the ISI would have been dependent mainly on foreign resources. 
Nevertheless, it is possible to see some evidence that the early planners succeeded in withstanding the private sector who demanded subsidies and more protection in the internal market during the first plan covering the years of 1962-1966. As Milor puts it on, the private sector persisted with setting up an automotive factory in the early 1960s. However, the SPO technocrats rejected the proposal due to the fact that it would not achieve economies of scale in the Turkish market (Milor, 1990, p. 22). Comparing to the first plan, it is difficult to find any evidence that the first planners implemented policy for a clear goal of industrialization regardless of the demands from the interest groups in the period of the second and the third plans, covering the years of 1968-1977.

The second plan was conducted under the governance of the Justice Party, which came into the power in 1965 election. In the first years of the JP government, Süleyman Demirel took power away from the SPO through legal acts and employee regime. Firstly, he swelled the rank of the technocrats, including with some new staff who were oblivious of the concept of planning (Kansu, 2004). Then, Demirel administration enacted Law No 933, which gave the council of ministers authorization on the planning process. In addition, the government established a new department within the SPO in accordance with this law in 1968, namely the Incentive and Implementation Department, which worked on project-based.

The bitter dispute between Demirel and the early planners was that the early planners espoused macroeconomic measures to sustain economic growth. To provide macroeconomic stability, the early planners had tried to perform tight monetary policy and had strict control over state incentives. However, with the implementation of Law No. 933, Demirel administration ladled out incentives to the private sector. The government expanded the incentive disbursement policy, it raised the amount of state incentives to 27 billion TL in 1972, while it disbursed 10.5 billion TL within last 3 years (Aker, 1975, p. 17). The new department, seemingly, was established to promote exports. However, it never functioned to fulfill its goal and became the apparatus of the government to divert public funds to the private sector (Sezen, 1999, pp. 90-92). Thus, the SPO deviated from its founding purpose, and lost the relative state autonomy. Its new duty was to create a rent-seeking economy.

Comparing East Asian developmental states, it can be observed that Turkey and Latin American countries could not achieve in transforming an inward-oriented economic growth to an outward-oriented one. Both in Japan, Korea and Taiwan, the bureaucratic elites shifted policy paradigm to force the private sector to the international market. In Japan's case, as Weiss puts it, after a high protection in the internal market, the MITI had devised a timetable of liberalization in some areas to improve the private sector efficiency so that Japanese firms could adapt to foreign competition (Weiss, 1986, p. 390). Similarly, in Korea's and Taiwan's experiences, selective import 
substitution furthered technologically-intensive and high-value-added exports in the 1980s (Gereffi \& Fonda, 1992).

In Turkey and Latin American Countries, on the other hand, the private sector was reluctant to promote export orientation because the business circle was protected by high tariffs from the international competition, and foreign resources were allocated desultorily to maintain import substitution. In these countries, the bureaucratic elites were open to the demands of interest groups rather directing the private sector to the export-oriented economic growth. The bureaucratic elites did not bear the consequences of shifting economy and buttressed the domestic coalition which was composed of businessmen, wage earners, and the salaried urban middle classes. For instance, during the ISI period, the wage rates in Turkey was quite higher than it was in Korea (Keyder, 2014). Consequently, import substitution industrialization was unable to exceed to produce durable consumer goods for the internal market in Turkey and Latin American countries (Baer, 1972; Pamuk, 2007).

Even though Turkey and Latin American countries suffered from same fate, the puzzle of why these countries failed at institutionalizing strong state autonomy varied across countries. Peter Evans, in his ground-breaking work Embedded Autonomy published in 1995, explains this puzzle by comparing Korea, Brazil, and India. In his formula, Korea, as a prototype of developmental state, achieved in performing longterm oriented development plans thank to the rationalized meritocratic-bureaucracy, which is embedded in society with social networks and other relations (Evans, 1995, pp. 51-53). Evans conceptualizes India and Brazil, on the other hand, as intermediary cases in which the state elites deprives of state autonomy to adapt the private sector to the long-term oriented development plans. To make clear, Evans draws attention to the precarity of the bureaucracy against politicians in Brazil preventing the establishment of a development state (Evans, 1995, pp. 61-66).

At this juncture, Turkey and India deserve close attention due to the fact that these countries have a long bureaucratic tradition. From the perspective of Evans' argument, even though it is possible to find some evidence showing similar personnel regime, the social structure of India is an obstacle to establish a developmental state (Evans, 1995, pp. 67-70). In Turkey's case, although the country has a long bureaucratic tradition since the Ottoman Empire, bureaucratic elites failed at directing private sector to the export-oriented economic growth. According to Chibber, the national bourgeoisie that made high profit behind protective tariffs, and weak ties with the multinational companies diminished the institutional capacity of the state (Chibber, 2005, 147).

At his point, it should be noted that Chibber's argument explaining the puzzle of why Turkish state elites had a weak state autonomy does not cover fully Turkey's case. There is no doubt that elected politicians had close networks with the private sector 
during the ISI years. However, elected politicians has never become the representatives of private sector neither in the 1960s nor today. Yet, the private sector was well aware of that the interconnectedness between the state and the economy might be disadvantageous to themselves. During the ISI period, elected politicians never fully met private sector's expectations (Saybaş1l, 1976). Elected politicians implemented policies aimed at satisfying the coalitions putting them into the power.

\section{Conclusion}

In this paper, I examined Turkey's experiences of the implementation of import substitution industrialization by referring to the literature on developmentalism and the developmental state. It is clear that the ISI strategy answered Turkey's longing desire to building a national industry. However, industrialization through import substitution succeeded with a heavy political and social cost. By the end of the 1970s, Turkey witnessed the most severe economic crisis in the history of modern republic and the country, after a long period of economic and social turmoil which started the new decade with the coup d'etat in September 1980.

Turkey's policy transformations in the years between 1946-1960 show that the international environment played a crucial role in shifting policy paradigm. However, the role of external international environment does not fully explain the puzzle of domestic policy decisions. New domestic coalitions, whose interests aligned with what the IO's prescribed, emerged as some of the domestic actors embedded their interest in the developmental policy transformation of Turkish State. As the landlords, merchants and the villagers, who were already dissatisfied with secular reforms, paved the way for of the electoral success of Democrat Party in 1950, we can see the emergence of a different coalition composition, which included industrialists, bureaucracy, and urban middle class, behind the policy shift to the ISI. In this sense, it can be asserted that the institutionalization of policies prescribed by the IOs is depended on the domestic coalitions.

In 1960, Turkey established a planning agency, the State Planning Organization, on the advice of the IOs. The SPO conducted the implementations of the ISI strategy with five years development plans. Even though the early planners had a strong support of the IOs and the army, they failed at actualizing their agenda. The early planners had aimed at adapting Turkish economy to the market criteria. They had also envisioned that the SPO would be the developmental state apparatus directing the private sector to the strategic industry. Their optimistic view ended with the rise of the Justice Party in 1965. IT can be asserted that the SPO initially had put up resistance to some of the expectations of the private sector and the elected politicians. However, the SPO technocrats lost their relative autonomy in the JP era. Would Turkey have succeeded the goal of industrialization without any social cost, if the SPO had had a state autonomy? 
It is obvious that answering this question is making a counter-factual speculation over the past history. When looking back, it can be seen that the main discrepancy between the elected politicians and the planners is the perception of economic development. While the SPO technocrats gave priority to the long-range economic plans for sustainable economic growth, the most important goal for the elected politicians was to achieve high-economic growth at any cost. The elected politicians were well aware that Turkey stepped into being a consumer society in the DP run era of the 1950sand tight fiscal policies proposed by the SPO was a major obstacle to high-economic growth. Moreover, the policy shift to the ISI strategy was based on a domestic coalition, and the elected politicians never dared to make bold attempts at disturbing or challenging this coalition. For the elected politicians, economic performance could be sustained as foreign resources -remittance and the foreign loansflowed into Turkish economy.

The elected politicians were uncomfortable with the SPO and the state bureaucracy. Süleyman Demirel, the leader of the Justice Party, had witnessed the coup d'etat when he was a senior officer of the DP administration. Yet, he was forced to resign from the prime ministry by the army in 1971 . For this reason, the elected politicians never felt secure in relation to the state bureaucracy. The feeling of insecurity motivated the elected politicians to make alliance with the private sector against the state bureaucracy. Naturally, this political-business alliance did not aim at transforming Turkish economy to the export-oriented growth, which required much sacrifices from the business community. The dream of early planners, namely shifting the strategy to the exportoriented growth model in the third stage of the ISI, needed a new domestic coalition. By the end of the 1970s, the IOs proposed, again, that Turkey should transform the ISI strategy to the export-oriented growth model. Yet, the history of Turkey's failed developmentalist visions from the 1950s to the 1970s repeated itself, as the new domestic coalitions emerged in the aftermath of the army coup in September 1980 to resist the state bureaucracy's plan for policies of industrial development.

Peer-review: Externally peer-reviewed.

Conflict of Interest: The author declare no potential conflicts of interest with respect to the research, authorship, and/or publication of this article.

Grant Support: The author received no financial support for the research, authorship, and/or publication of this article.

\section{References}

Ahmad, F. (2007). Bir kimlik peşinde Türkiye (S. C. Karadeli, trans.). Bilgi Üniversitesi Yayınları. Akçay, U. (2007). Kapitalizmi planlamak: Türkiye'de planlama ve DPT'nin dönüşümü. Sosyal Araştırmalar Vakfi.

Aker, A. (1975). 12 Mart döneminde dışa bağımlı tekelleşme. Sander Yayınlar.

Amsden, A. H. (1989). Asia' 'a next giant: South Korea and late industrialization. Oxford University Press. 
Baer, W. (1972). Import substitution and industrialization in Latin America: Experiences and interpretations. The Latin American Studies Association, 7(1), 95-122.

Baer, W. (1984). Industrialization in Latin America: Successes and failures. Journal of Economic Education, 15(2), 124-135.

Bağdat Paktı'nın İstikameti. (1958). Forum Dergisi, 93.

Barker, J. (1952). The economy of Turkey, an analysis and recommendations for a development program. John Hopkins University Press.

Barnett, M., \& Fiennemore, M. (2004). The rules for the world: International organizations in global politics. Cornell University Press.

Berkes, N. (1997). Unutulan yıllar. İletişim Yayınları.

Birtek, F. (1995). Devletçiliğin yükselişi ve düşüşü 1932-1950. In N. Çoşar (Ed.), Türkiye'de devletçilik (pp. 143-171). Bağlam Yayınları.

Boratav, K. (1993). Türkiye'de sanayileşmenin yeni boyutları ve KIT'ler. Tarih Vakfı Yayınları.

Boratav, K. (1995). Devletçilik ve Kemalist iktisat politikaları. In N. Çoşar (Ed.), Türkiye'de devletçilik. (pp. 115-142). Bağlam Yayınları.

Boratav, K. (1998). Türkiye iktisat tarihi 1908-1985. Gerçek Yayınevi.

Buğra, A. (1991). Political sources of uncertainty in business life. In M. Heper (Ed.), Strong state and economic interest groups: The Post-1980 Turkish experiences (pp. 151-162). Walter de Gruyter.

Chibber, V. (2005). Reviving the developmental state? The myth of the 'national bourgeoisie'. Socialist Register, 41, 144-165.

Çeçen, A., Doğrul, S., \& Doğruel, F. (1994). Economic growth and structural change in Turkey 1960-1988. International Journal of Middle Eastern Studies, 26(1), 37-56.

Erder, N., Çilingiroğlu, A., Karaosmanoğlu A., \& Sönmez, A. (2003). Planlı kalkınma serüveni: 1960 'larda Türkiye'de planlı kalkınma deneyimi. Bilgi Üniversitesi Yayınları.

Ergüder, Ü. (1970). Politics of agricultural taxation in Turkey: 1945-1965 (Doctoral dissertation). Syracuse University.

Evans, P. (1995). Embedded autonomy: States \& industrial transformation. Princeton University Press.

Gereffi, G., \& Fonda, S. (1992). The regional paths of development. Annual Review of Sociology, $18,419-448$.

Hirschman, A. O. (1967). Development project observed. Brooking Institution.

Johnson, C. (1982). MITI and the Japanese miracle: The growth of industrial policy, 1925-1975. Stanford University Press.

Johnson, C. (1999). The developmental state: Odysse of a concept. In M. Woo-Cumings (Ed.), The Developmental state (pp. 32-60). Cornell University Press.

Kansu, G. (2004). Planlı yıllar (Anılarla DPT’nin öyküsü). Türkiye İş Bankası Kültür Yayınları.

Karaömerlioğlu, A. (2006). Türkiye'de çok partili demokrasiye dönüşün toplumsal dinamikleri. Toplum ve Bilim, 106, 174-191.

Kayalı, K. (2015). Ordu ve siyaset, 27 Mayıs-12 Mart. İletişim Yayınları.

Karaosmanoğlu, Y. (1968). Politikada 45 yll. Bilgi Yayınları. 
Karpat, K. (1962). Recent developments in Turkey and their social background. International Affairs, 38(3), 304-323.

Karpat, K. (2007). Türkiye'de siyasal sistemin evrimi: 1876-1980 (E. Soğanc1lar, trans). İmge Kitabevi Yayınlar1.

Kerwin, R. W. (1995). Türkiye'de devletçilik 1933-1950. In N. Çoşar (Ed.), Türkiye'de devletçilik (pp. 97-114). Bağlam Yayınları.

Keyder, Ç. (2014). Türkiye'de devlet ve sinıflar. İletişim Yayınları.

Köker, L. (2007). Modernleşme, Kemalizm ve demokrasi. İletişim Yayınları.

Loriaux, M. (1999). The French developmental state as myth and moral ambition. In M. Woo-Cumings (Ed.), The developmental state (pp. 235-275). Cornell University Press.

Maxfield, S., \& Noldt, J. (1990). Protectionism and the internationalization of capital: U.S. sponsorship of import substitution industrialization in the Philippines, Turkey, and Argentina. International Studies Quarterly, 34(1), 49-81.

Meyer, J. M., Boli, J., Thomas, G. M., \& Ramirez, F. O. (1997). World society and the nation state. American Journal of Sociology, 103, 144-181.

Mihçıŏlu, C. (1983). Devlet Planlama Örgütünün kuruluş günleri. In X. XXX (Ed.), Prof. Fadıl H. Sur'un Anısına Armağan (pp. 229-257). AÜSBF Yayınları.

Milor, V. (1990). The genesis of planning in Turkey. New Perspectives on Turkey, 4, 1-30.

Oksay, K. (1967). Guide to foreign capital investment in Turkey. Ankara Üniversitesi Basım Evi.

Okyar, O. (1954). Planlı iktisat rejimi. Forum Dergisi, 16, 6-7.

Okyar, O. (1957). Planlama Tarihçesine Müteallik Notlar. Forum Dergisi, No: 89, pp.15-16.

Okyar, O. (1960). The Turkish stabilization experiment -before and after. Middle Eastern Affairs, 8 , 238-246.

Owen, R., \& Pamuk, Ş. (1999). A history of Middle Eastern economies in the $20^{\text {th }}$ century. Tauris.

Öniş, Z., \& Şenses, F. (2016). Küresel dinamikler, ülke içi koalisyonlar ve reaktif devlet: Türkiye'nin savaş sonrasında önemli politika dönüşümleri. In F. Şenses (Ed.), Neoliberal küreselleşme ve kalkınma (pp. 705-744). İletişim Yayınları.

Pamuk, Ş. (1991). War, state economic policies, and resistance by agricultural producers in Turkey, 1939-1945. In F. Kazemi \& J. Waterbury (Eds.), Peasants and politics in the modern Middle East (pp. 125-142). Florida International University Press.

Pamuk, Ş. (2007). Osmanlıdan Cumhuriyete küreselleşme, iktisat politikaları ve büyüme. Türkiye İş Bankası Kültür Yayınları.

Sakıp, Ö. (1957). Demokratik devrim üzerine düşünceler. Forum Dergisi, 83, 7-8.

Sakıp, Ö. (1958). Program ve plan tartışmaları. Forum Dergisi, 114, 8.

Saybaşı11, K. (1976). Türkiye'de özel teşebbüs ve ekonomi politikası. ODTÜ Gelişme Dergisi, 13, 83-97.

Sezen, S. (1999). Devletçilikten özelleştirmeye Türkiye'de planlama. TODAİ.

Silva, E. (2007). The import substitution model: Chile in comparative perspective. Latin American Perspectives, 34, 67-90.

Singer, M. (1977). The economic advance of Turkey, 1938-1960. Turkish Economic Society Publication.

Soral, E. (1971). Özel kesimde Türk müteşebbisleri ve kapitalist kalkınma yolu. AİTİA. 
Sönmez, A. (1967). The re-emergence of the idea of planning and the scope and targets of the 19631967 Plan. In S. İlkin \& E. İnanç (Eds.), Planning in Turkey (pp. 28-43). METU.

Şaylan, G. (1981). Planlama ve bürokrasi [Özel Say1]. ODTÜ Gelişme Dergisi, 183-205.

Tekeli, İ., \& İlkin, S. (1982). Uygulamaya geçerken Türkiye'de devletçiliğin oluşumu. ODTÜ Yayınları.

Tekinalp, M. (1949). Yabancı sermaye neden Türkiye’ye can atmıyor? Türkiye İktisat Mecmuası, $22,14-16$.

Thornbug, M. W. (1949). Turkey: An economic appraisal. Twenty First Century Fund.

Torun, O. N. (1967). The establishment and the structure of the State Planning Organization. In S. İlkin \& E. İnanç (Eds.), Planning in Turkey (pp. 44-70). METU.

Tüzün, G. (1999). 1950-1960 döneminde sanayileşme. In O. Baydar (Ed.), 75 yılda çarklardan çiplere (pp. 147-166). Tarih Vakfi Yayınları.

Üstünel, B. (1967). Problems of development financing: Turkish case. Journal of Development Studies, 3, 130-154.

Weiss, J. (1986). Japan's post-war protection: Some implications for less developed countries. The Journal of Development Studies, 22(2), 385-406.

Woo-Cumings, M. (1999). Chalmers Johnson and the politics of nationalism and development. In M. Woo-Cumings (Ed.), The developmental state (pp. 1-31). Cornell University Press.

Yalçın, A. (1956a). İktisadi planlama ve kalkınma. Forum Dergisi, 49, 10-11.

Yalçın, A. (1956b). John Maynard Keynes. Forum Dergisi, 51, 17-18.

Zürcher, E. J. (2004). Modernleşen Türkiye'nin tarihi (Y. Saner Gören, trans.). İletişim Yayınları. 
